pages-had to be printed in a single week from the time the first batches of manuscript were received by Dr. McMurrich. Indeed, most of the program manuscripts did not reach him till December 20 and 21, and the book was completed by noon on December 24 . The University of Toronto Press gave very efficient and really wonderful service in this connection.

The registration room, in charge of the executive assistant, Mr. Sam Woodley, was conveniently and centrally located, in the library building of the university. An able corps of assistants was provided, and the work of the registration office went forward with exceptional smoothness. The same form of visible directory as was used at the last annual meeting was employed at Toronto, and this again proved to be a valuable feature of the meeting. By this plan, a continuously corrected list of those in attendance, with their home addresses and those for the meeting, is kept convenient for public consultation in the registration room. The assistant secretary, Dr. Sam F. Trelease, assisted the permanent secretary in many ways, aside from his work as secretary of the council. He gave valuable service in the editing of the manuscripts for the general program before they were sent to Toronto be printed. He has also helped very much in the preparation of the present paper. and the other reports of the meeting that are to be published in ScIEnce.

Publicity was unusually well handled at the Toronto meeting. As was announced in the preliminary announcement and also in Scrence before the meeting, the recently organized Science Service cooperated with the association in arousing public interest in the meeting, through the daily press. Dr. E. E. Slosson, editor of Seience Service, and Mr. Watson Davis were present throughout the meeting, on behalf of the Science Service. Many of the papers occurring on the programs at Toronto were given attention in the weekly "Science News Bulletin" sent to newspapers by the Science Service for the week of the meeting, and many dailies received each day from the service a 500-word telegraphic report on the meeting.
Besides the valuable publicity work of the Seience Service, which is under the control of the American Association, the U. S. National Academy and the U. S. National Research Council, and which operates for the sole pur. pose of disseminating scientific knowledge through the newspapers, just as valuable and efficient publicity work was accomplished by the Local Subcommittee on Publicity, of which Professor A. G. Huntsman was chairman. At Professor Huntsman's suggestion, a new feature was introduced this year by the permanent secretary's office. As the manuseripts for the general program came in during the week preceding Christmas day, the names of all speakers were copied off, after which the manuscripts were edited and forwarded to Toronto for printing. To each name occurring on each day's list was addressed a letter asking for an abstract of the paper to be given at Toronto by that individual, and enclosing a blank form for this abstract, to be returned to Professor Huntsman. This work had to be done with great rapidity, but large numbers of abstracts were received and these furnished material for the work of the Subcommittee on Publicity. It seems desirable to develop this feature of special personal requests for abstracts and to retain it for future annual meetings of the association. Professor Huntsman and his colleagues used the abstracts as they came in, so as to have representative and suitable material ready for the newspapers during the meeting, and they thus secured for the association unusually excellent and exceptionally satisfactory treatment by the daily press of Toronto and other cities.

A report of the proceedings of the Council at Toronto will appear in a later issue of ScIence.

Burton E. Livingston, Permanent Secretary.

\section{CAROLINE BURLING THOMPSON 1869-1921}

Dr. Caroline Burling Thompson, professor of zoology at Wellesley College, died on December 5, 1921. Professor Thompson was noted not only for the excellence and thoroughness of her original methods of teaching, but also 
for her original research work in biology. She was an inspiration to her students and also found means of helping them in many practical ways, unknown to any but herself.

Miss Thompson did original research work in biology in connection with the marine laboratories both at Naples, Italy, and Woods Hole, Mass. Her most noted work was on the biology of termites-the most destructive of the social insects. She has been a collaborator of the Branch of Forest Entomology, Bureau of Entomology, U. S. Department of Agriculture, since March, 1917.

1916 saw Miss Thompson's first paper on termites. It was an original piece of research on the brain and frontal gland of a common termite of eastern United States. She discovered that there was very little differentiation between the brains of the different castes of this termite and none between the sexes, the most marked difference being in the optic apparatus. Miss Thompson suggests that the frontal gland may have arisen phylogenetically from the ancestral median ocellus now lacking. This work was of considerable importance, since the frontal gland is of great taxonomic value.

In 1917, a paper on the origin of the castes of a common termite revolutionized the attitude taken by students of termites. Hitherto the attitude had been almost entirely anthropocentrie; Dr. Thompson disproved that the "eomplementary" or "substitute" queens or reproductive forms of termites could be manufactured through feeding by workers. She definitely proved that the origin of all castes is due to intrinsic causes. Thus, by careful seientific study, much of the mystery of the "complex" social system of the termiteswhich has led to admiration by man of these insects-has been proved a myth. Facts now supplant the older fantastic theories, so dear to writers of the eighteenth and nineteenth centuries.

Another paper in 1919 discussed the phylogeny of the termite castes and outlined breeding experiments which were in progress at the time of her death. It was hoped to work out a genetic formula for termites.

These papers were followed by several others on the development of the eastes and reproductive forms of species of many genera of termites.

Work on the development of the castes of the honey bee had been planned and material fixed ready to section. It is to be regretted that ill health and other duties interfered. Miss Thompson was undertaking this work as she ever did with an open mind-realizing that very careful work had been done on the honey bee and that no generalizations could be made in advance. The social insects often radically differ in habits. What might be an anthropocentrism in case of the termites, might be a fact in the biology of the honey bee!

With two other co-workers, Miss Thompson was working on a more or less popular book on termites and her share was to be the internal anatomy of termites as well as phylogeny and genetic work.

A kindly, helpful spirit, of keen mind, but modest-Miss Thompson will be long remembered by her students and co-workers in science. A striking point in Dr. Thompson's personality, in fact its key note and which signalized her as an investigator and as a teacher, is that with all her splendid training and her admirable technique she was not biased by the current fashions of the school in which she was trained, but struck out into new fields. Her own research work will endure forever!

Washington, D. C.

T. E. S.

DECEMBER 10, 1921.

\section{SCIENTIFIC EVENTS}

\section{THE HECKSCHER RESEARCH FOUNDATION}

THE following grants have been made during the year 1921 by the Heckscher Research Foundation for the support of investigation at Cornell University:

1. To Professor J. Q. Adams a sum sufficient to secure his release from the duties of teaching for the first term of the year 1921-1922, to enable him to complete his book on "The Life of Shakespeare."

2. $\$ 2,000$ to Professor C. C. Bidwell to enable him to carry on cryogenic measurements, and to study the relation between eleetrical conductivity and temperature for so-ealled "variable" conductors. 